\title{
AKIŲ PRIEŽIŪRA INTENSYVIOSIOS TERAPIJOS SKYRIUJE
}

\author{
Laurynas Kanapeckas, Vita Marčiulionytė, Paulius Vargalis \\ Lietuvos sveikatos mokslu universiteto Medicinos akademijos Medicinos fakultetas
}

Raktažodžiai: akių ligos, akių priežiūra, intensyviosios terapijos skyrius, ekspozicinè keratopatija, chemozè, keratitas, konjunktyvitas.

\section{Santrauka \\ Mokslinèje literatūroje daugejja ịrodymų, jog intensyvio- sios terapijos skyriuose (ITS) medikai, sutelkę veiksmus i gyvybę palaikančias intervencijas, apleidžia kritinès būklès pacientų akių priežiūrą. Šiuose skyriuose gydomi sunkios būklès pacientai, dažnai be sąmonès, jiems tai- koma sedacija, todèl reikšmingai susilpnèja fiziologi- niai akių apsauginiai mechanizmai (išnyksta mirksējimo refleksas, nevisiškai užmerkiamos akys, sutrinka ašarų išsiskyrimas bei ašarų plèvelès funkcija) ir padidejja akiu ligų rizika. Šiame darbe analizuojamos mokslinès publi- kacijos, kuriose aprašytos dažniausiai ITS nustatomos akių ligos ar būklès: ekspozicinè keratopatija, chemozè, mikroorganizmų sukelti keratitai ar konjunktyvitai. Rasta publikacijų apie akių priežiūrą, patologijų prevenciją. Apibendrinus rezultatus, padarytos išvados, jog akių pa- žeidimai ITS yra dažni, jų galima išvengti ar sumažinti riziką, pritaikius akių priežiūros protokolus. Dažniausiai patogenai patenka ant junginès ir ją kolonizuoja, atliekant intervencijas, kurių metu iš kvèpavimo takų išsiskiria aerozoliai. İvertinus atliktus tyrimus, pastebeta, jog bar- jeriniai akių tvarsčiai iš polietileno laikomi efektyviausia prevencine priemone, siekiant išvengti akių paviršiaus pažeidimo, lyginant su ịprastiniais metodais, kai akys už- merkiamos ir užklijuojamos pleistru. Rasta publikacijų, įrodančių, jog organizuojant ITS darbuotojų edukacijos programas, galima užtikrinti kokybišką akių priežiūrą ir išvengti dažniausių akių ligų pasireiškimo.}

\section{İvadas}

Sveikų žmonių akyse yra fiziologinių gynybos mechanizmų, kurie saugo akių paviršių nuo pažeidimo. Junginė ir ragenos epitelis saugo akies paviršių nuo mechaninių sužalojimų ir mikroorganizmų, ašarų plèvelè palaiko ragenos vientisumą, suteikdama drègną ir deguonies prisotintą aplinką, bei maistines medžiagas epitelio ląstelèms. Ji patepa akių vokus, išplauna svetimkūnius ir neleidžia mikroorganizmams likti akių paviršiuje. Užsimerkimas bei mirksèjimo refleksas sukuria mechaninę kliūtị traumai, akių išsausèjimui, neleidžia išgaruoti ašaroms [1]. Šie mechanizmai negali veikti, kai, pavyzdžiui, dèl sunkios patologijos ITS pacientas neturi sąmonès. Dèl kritinès būklès pacientų gynybos mechanizmų susilpnèjimo gali išsausèti ragena, atsirasti išopèjimas, perforacija, infekcija, susidaryti randu, o tai gali rimtai pakenkti regejjimo aštrumui ir gyvenimo kokybei. Konjunktyvitas, chemozè (junginès edema), lagoftalmas (patologinis nevisiškas vokų susiglaudimas), ragenos abrazija (paviršinis epitelio sužalojimas), ekspoziciné keratopatija (ragenos džiūvimas, sukeliantis epitelio sužalojimą), sausos akys ir endoftalmitas (uždegimas, pažeidžiantis akies obuolio vidų) yra pagrindinès akių komplikacijos ITS [2]. Šiame skyriuje akių priežiūra dažnai apleidžiama, nes medikai sutelkia savo veiksmus i kritinès būklès pacientų gyvybę palaikančias intervencijas. Akių priežiūros protokolų prièmimas ir ịgyvendinimas gali užkirsti kelią šių su ekspozicija susijusių komplikacijų išsivystymui ir vèlesniam sergamumui akių ligomis.

Tyrimo tikslas - apžvelgti prieinamą mokslinę literatūrą apie dažniausiai pasitaikančias akių ligas ir intensyviosios terapijos skyriaus pacientų akių priežiūrą.

\section{Tyrimo medžiaga ir metodai}

Publikacijų paieška atlikta kompiuterinèse bibliografinėse mokslinių darbų bazėse PubMed, ScienceDirect, ResearchGate, naudojant raktinius žodžius ir jų derinius: eye care, eye disease, intensive care unit, critical care, occular disorders.

\section{Rezultatai ir jų aptarimas}

\section{Dažniausi pažeidimai ir ligos}

Ekspozicine keratopatija - patologija, kuri atsiranda išsausejjus ragenai dèl ilgo išorès poveikio, pvz., sutrikus mirksejjimui. P. Parekh ir bendraautorių [2] apžvalgoje teigiama, jog ši patologija labai dažna, netaikant reikiamos priežiūros, išsivysto 3,6-60 proc. ITS pacientų. Ši būklè sutrikdo ragenos barjero apsauginę funkciją, todèl didejja infekcinio keratito, ragenos opų ar net perforacijos rizika. Tyrime atskleista, jog ITS naudojami raminamieji ar miorelaksantai slopina mirkséjimo refleksą ir žiedinio akies raumens susitraukimą, todèl atsiranda lagoftalmas. Akis ne visiškai užmerkiama, dèl ilgalaikio kontakto su oru išgaruoja ašaros, suyra ašarų plèvelè, 
todèl pažeidžiama ragena. Panašūs pastebèjimai aprašyti ir B. Bird su bendraautoriais [3] apžvalgoje. Mokslininkai pristate tris klinikinius atvejus ir pastebejo, jog didžiausią ịtaką ekspozicinès keratopatijos atsiradimui turi gydymo ITS trukmè ir taikytos akių priežiūros kokybė, bei ankstesni predisponuojantys veiksniai, tokie kaip egzoftalmas (akies obuolio pasislinkimas i prieki), akies vokų operacijos ir kt. Abiejose minètose publikacijose aprašoma, jog padidèjęs kraujagyslių laidumas, teigiamo slègio ventiliacija, elektrolitų disbalansas sukelia junginès edemą ir neleidžia visiškai užmerkti akių. Siekiant išvengti akių pažeidimo ITS, labai svarbu pastebèti net ir nedidelị lagoftalmą ir taikyti reikiamą priežiūrą.

Chemozè. Chemozės dažnis siekia nuo 9 iki 80 proc. ITS pacientų. Ragenos edema, dar kitaip vadinama chemoze, yra dažna būklè, galinti sukelti rimtų komplikacijų. Teigiamo slègio ventiliacija padidina venini slègi, todèl sutrinka veninio kraujo nutekejjimas iš akies struktūrų. Tai sukelia skysčio kaupimąsi periokuliniuose audiniuose ir chemozę. Kritinès būklès pacientams dažnai būdingas skysčiu perteklius, elektrolitų pusiausvyros sutrikimas, padidèjęs kapiliarų laidumas ir mažas onkotinis slègis plazmoje, atsirandantis dèl hipoproteinemijos, kurią sukelia metaboliniai sutrikimai. Visi veiksniai, susiję su ilgalaikiu nejudrumu, sukelia veido edemą ir chemozę (ypač ant pilvo gulintiems pacientams). Dèl chemozès akių vokai nevisiškai užsimerkia, todèl galima ekspozicinè keratopatija, mikroorganizmų sukeltas keratitas. F. Mercieca ir kiti [5] savo tyrime aprašè dažną ( 80 \%) ragenos edemos pasireiškimą ITS pacientams, o $92 \%$ pacientu, turinčių lagoftalmą, pasireiškè tam tikro laipsnio chemozè. Tai leidžia manyti, kad chemozè išsivysto del ilgalaikès akies ekspozicijos aplinkoje arba kaip pirminis veiksnys, sutrikdantis akies užmerkimą. Dažnesnis chemozès pasireiškimas pastebėtas ventiliuojamiems pacientams, kuriems lagoftalmas išsivysto dèl gilios sedacijos ir raumenų relaksacijos [5].

Infekcinis konjunktyvitas ir keratitas. A. Grixti ir kt. [4] literatūros apžvalgoje teigiama, jog ITS yra didelè rizika susirgti mikroorganizmų sukeltu junginès ir ragenos uždegimu dèl ekspozicinès keratopatijos sukelto pažeidimo bei taikomų intervencijų, pavyzdžiui, teigiamo slègio ventiliacijos, sukeliančios junginès paburkimą. ITS aplinkoje dèl plataus antibiotikų vartojimo gausu atsparių bakterijų rūšių. Dažniausias nustatytas patogenas Pseudomonas aeruginosa, kuris ị akis patenka iš kvejpavimo takų, atliekant endrotrachejjinį siurbimą ar iš tracheostomos lauko. T. Saritas ir bendraautorių [6] retrospektyviajame tyrime rasta, jog iš 40 tirtu junginès pasėlių $17(42,5 \%)$ buvo rastos bakterijos: dešimtyje - Staphylococcus epidermidis, dviejuose - Pseudomonas aeruginosa, dviejuose - Acinetobacter baumannii, viename - Staphylococcus haemolyticus, viename - Klebsiella ir viename - Proteus mirabilis. Statistiškai reikšmingo skirtumo tarp junginès pasèlių tiriamiesiems su mechanine ventiliacija ir be jos, su sedacija ir be jos, su inotropais ir be jų, nebuvo $(\mathrm{P}>0,05)$. Dviems pacientams, sergantiems keratitu, ragenos, junginès bei trachèjos pasèliuose rasta Pseudomonas aeruginosa ir Acinobacter baumannii. E. Mela kartu su kitais autoriais [7] ištyrè nuo laiko priklausomą seduotų pacientų ITS akių paviršių kolonizavimą bakterijomis ir ịvertino, ar tinkama lokali antibiotikų profilaktika galètų padèti išvengti ragenos uždegimo. 54 pacientu junginių pasèliuose iš tirtų $70(77 \%)$ nustatyta bent vieno mikroorganizmo kolonizacija per 7-42 dienas, kai buvo taikyta sedacija. Šio tyrimo rezultatai parodè, kad ankstyvas akiu paviršiaus bakteriju kolonizacijos nustatymas ir profilaktinis gydymas vietiniais antibiotikais gali užkirsti kelią ragenos infekcijai didelès rizikos ITS pacientams.

Akiu priežiūra ITS. M. Alansari ir kt. [8] sisteminèje literatūros apžvalgoje analizuotos priemonès, kurios taikomos ITS sumažinti akių pažeidimo riziką. Pirmiausia, akies vokų padèties apžiūra. Tais atvejais, kai atsiranda epitelio defektas, tikslinga anksti užverti akies plyši apatini voką sutraukiančia siūle, paliekant galimybę ištirti akị vèliau ir kuo greičiau kreiptis ị oftalmologus. Profilaktinis vietinio poveikio antibiotikų vartojimas gali būti labai naudingas, norint išvengti akies paviršiaus sausumo ar antrinès infekcijos. Daugelyje tyrimų nustatyta, kad polietileno danga, veiksmingiau nei kitos priemonès, ITS pacientus apsaugo nuo sausų akių sindromo $(\mathrm{P}<0,01)$.

Aprašyti ịvairūs metodai, išvengti ekspozicinès keratopatijos:

- užmerkti ir užklijuoti pleistru akis gali būti veiksminga, tačiau, jei nèra taikomos papildomos priemonès, akys nepakankamai drèkinamos ir epitelio pažaidos išvengti nepavyksta. Siekiant išvengti ekspozicinès keratopatijos, drèkinamasis akių tepalas veiksmingesnis, nei vien tik akių užmerkimas [9];

- akių pleistras su skydeliu iš polietileno apsaugo akị nuo įbrèžimų ir padeda sulaikyti drègmę. Tokio pleistro pranašumas yra jo papildoma barjerinè funkcija, sauganti akis nuo užteršimo aerozolius generuojančių procedūrų metu ar aplinkos mikroorganizmais [10];

- prieš tepimą drékinamuoju tepalu, akys turi būti plaunamos šiltu vandeniu, pašalinant išdžiūvusius tepalo likučius. Prieš lašinant dirbtines ašaras, ar tepant drėkinamuoju tepalu, akys turi būti apžiūrètos dèl raudonumo, chemozès, ragenos pokyčių. Jei tokių pokyčių yra, gali prireikti oftalmologo konsultacijos [11].

O. Cho ir kiti autoriai [12] pastebèjo, kad akių priežiūra ITS pagerẻja, jei slaugytojai išklauso specialius kursus. Personalo žinios apie akių priežiūrą, dažniausiai pasitaikančias ligas ir jų prevenciją ženkliai pagerèjo po tokių mokymų. İvedus edukacinę akių priežiūros ITS programą, galima suvienodinti procedūras ir sumažinti akių pažeidimų dažnį. 


\section{Išvados}

1. Akių pažeidimai intensyviosios terapijos skyriuose yra dažni, jų galima išvengti ar sumažinti riziką, taikant akių priežiūros protokolus.

2. Dažniausiai ITS pasitaikančios akių ligos yra ekspozicinè keratopatija, chemozè ir mikroorganizmų sukeltas keratitas ar konjunktyvitas. Infekcinį akies paviršiaus uždegimą dažniausiai sukelia Pseudomonas aeruginosa, vykdant intervencijas, kurių metu iš kvėpavimo takų išsiskiria aerozoliai.

3. Barjeriniai akių tvarsčiai iš polietileno laikomi efektyviausia prevencine priemone, siekiant išvengti akių paviršiaus pažeidimo, lyginant su ịprastiniais metodais, kai akys užmerkiamos ir užklijuojamos pleistru.

4. İvedus edukacinę akių priežiūros intensyviosios terapijos skyriuje programą, galima suvienodinti procedūras ir sumažinti akių pažeidimų pasireiškimo dažnị.

\section{Literatūra}

1. Sack RA, Nunes I, Beaton A, Morris C. Host-defense mechanism of the ocular surfaces. Biosci Rep 2001;21(4):463-80. https://doi.org/10.1023/A:1017943826684

2. Parekh PH, Boente CS, Boente RD, Meeker JW, Carlos WG. Ophthalmology in critical care. Ann Am Thorac Soc 2019;16(8):957-66.

https://doi.org/10.1513/AnnalsATS.201812-848CME

3. Bird B, Dingley S, Stawicki SP, Wojda TR. Exposure keratopathy in the intensive care unit: do not neglect the unseen. Vignettes Patient Saf 2018; (2):131-150. https://doi.org/10.5772/intechopen.72791

4. Grixti A, Sadri M, Edgar J, Datta AV. Common ocular surface disorders in patients in intensive care units. Ocul Surf 2012;10(1):26-42. https://doi.org/10.1016/j.jtos.2011.10.001

5. Mercieca F, Suresh P, Morton A, Tullo A. Ocular surface disease in intensive care unit patients. Eye 1999;13(2):231-6. https://doi.org/10.1038/eye.1999.57

6. Saritas TB, Bozkurt B, Simsek B, Cakmak Z, Ozdemir M, Yosunkaya A. Ocular surface disorders in intensive care unit patients in a Sub-Saharan teaching hospital. J Emerg Intensive Care Med 2012;11(1). https://doi.org/10.1155/2013/182038

7. Mela EK, Drimtzias EG, Christofidou MK, Filos KS, Anastassiou ED, Gartaganis SP. Ocular surface bacterial colonisation in sedated intensive care unit patients. Anaesth Intensive Care 2010;38(1):190-3. https://doi.org/10.1177/0310057X1003800129

8. Alansari MA, Hijazi MH, Maghrabi KA. Making a difference in eye care of the critically ill patients. J Intensive Care Med 2015;30(6):311-7. https://doi.org/10.1177/0885066613510674

9. Lenart SB, Garrity JA. Eye care for patients receiving neuromuscular blocking agents or propofol during mechanical ventilation. Am J Crit Care 2000;9(3):188-91.

https://doi.org/10.4037/ajcc2000.9.3.188

10. So HM, Lee CCH, Leung AKH, Lim JMJA, Chan CSC, Yan WW. Comparing the effectiveness of polyethylene covers $\left(\right.$ Gladwrap $^{\mathrm{TM}}$ ) with lanolin (Duratears ${ }^{\mathbb{R}}$ ) eye ointment to prevent corneal abrasions in critically ill patients: a randomized controlled trial. Int J Nurs Stud 2008;45(11):1565-71.

https://doi.org/10.1016/j.ijnurstu.2008.02.005

11. Hearne BJ, Hearne EG, Montgomery H, Lightman SL. Eye care in the intensive care unit. J Intensive Care Soc 2018;19(4):34550 . https://doi.org/10.1177/1751143718764529

12. Cho OH, Yoo YS, Yun SH, Hwang KH. Development and validation of an eye care educational programme for intensive care unit nurses. J Clin Nurs 2017;26(13-14):2073-82.

https://doi.org/10.1111/jocn.13635

\section{EYE CARE IN INTENSIVE CARE UNIT}

L. Kanapeckas, V. Marčiulionytė, P. Vargalis

Keywords: eyes disease; eye care; intensive care unit; exposure keratopathy; chemosis; keratitis; conjunctivitis.

Summary

There is growing evidence in the scientific literature that physicians in intensive care units (ICUs) neglect eye care for critically ill patients when focusing on life-sustaining interventions. Patients treated in these wards are often unconscious, sedated: it significantly weakens the physiological mechanisms of eye protection (loss of blink reflex, incomplete lid closure, impaired tear secretion and tear film function) and increases the risk of eye diseases. We analysed scientific literature that describe the most common eye diseases or conditions detected in the ICU: exposure keratopathy, chemosis, microbial keratitis or conjunctivitis. Publications on eye care and prevention have also been found. Summarizing the results, it was concluded that ocular surface disorders in ICUs are quite common: they can be prevented by applying eye care protocols. Infections of the ocular surface usually occur during interventions that release aerosols from airways, allowing pathogens to colonize the conjunctiva. Research has shown that polyethylene barrier eye bandages are considered to be the most effective measure to prevent damage to the ocular surface compared to conventional methods of closing and patching the eyes. Publications also state that ICU's staff education programs can ensure high-quality eye care and prevent the occurrence of the most common eye diseases.

Conclusions. 1. Ocular surface disorders are common in intensive care units, they can be prevented by applying eye care protocols. 2. The most common ocular disorders in ICU are exposure keratopathy, chemosis and microbial keratitis or conjunctivitis. Infections of the ocular surface are most commonly caused by Pseudomonas aeruginosa during interventions that release aerosols from airways. 3. Barrier eye bandages made of polyethylene are considered to be the most effective measure to prevent damage to the surface of the eye compared to conventional methods when the eyes are closed and patched. 4. Introduction of an educational program on eye care in the intensive care unit can not only standartize procedures, but also reduce the incidence of eye lesions.

Correspondence to: v.marciulionyte@gmail.com

Gauta 2020-05-26 